\title{
IDENTIFIKASI PTERIDOPHYTA DI PIKET NOL PRONOJIWO LUMAJANG SEBAGAI SUMBER BELAJAR BIOLOGI
}

\author{
Miftakhul Jannah, Wahyu Prihanta, Eko susetyorini. \\ ${ }^{1}$ Pendidikan Biologi FKIP Universtias Muhammadiyah Malang, \\ e-mail: mifta_cute70@yahoo.co.id
}

\begin{abstract}
Indonesia has abundant Pteridophyta, because Indonesia has a climate that supports the growth of Pteridophyta. Pteridophyta are found in tropical forests which have abundant sunlight and high humidity. Pronojiwo have characteristics suitable forest for life pteridophyta.This type of research is descriptive research. Research will be conducted in two places, pteridophyta samples implemented Piket Nol Pronojiwo Lumajang and FGD in Mataram Lumajang high school
\end{abstract}

Keywords: Pteridhophyta, Piket Nol Lumajang, FGD

Pteridophyta memiliki habitat tersebar di seluruh bagian bumi, namun paling banyak ditemukan hidup di tropika. Menurut Tjitrosomo et.al (1983), Pteridhopyta hidup tersebar luas dari tropika yang lembab sampai melampaui lingkaran artika. Jumlah yang sangat besar dijumpai di hutan-hutan hujan tropika dan juga tumbuh dengan subur di daerah beriklim sedang.

Pteridophyta memiliki anggota jenis yang cukup besar, menurut Jones dan Luchsinger (1986) di seluruh dunia ditemukan 13.000 species Pteridophyta. Di Malaya yaitu kawasan yang meliputi sebagian besar kepulauan Indonesia, Philipina, Guinea dan Australia Utara, terdapat 4.000 species Pteridophyta yang mayoritas anggota Kelas Filicinae (Whitten dan Whitten 1995). Menurut Loveless (1999), Pteridophyta memiliki 10.000 species, $\quad 3.000$ diantaranya diperkirakan hidup di Indonesia.

Indonesia memiliki jumlah Pteridophyta yang melimpah karena Indonesia memiliki iklim yang mendukung pertumbuhan Pteridophyta. Pteridophyta banyak ditemukan pada hutan tropika yang memiliki cahaya matahari melimpah dan kelembaban tinggi. Di hutan tropika Pteridophyta menempati habitat yang ternaungi seperti epifit pada pepohonan atau pada dasar lantai hutan yang lembab, Pteridophyta di hutan terlindung dari panas dan angin kencang. Beberapa jenis Pteridophyta dapat di temukan di lahan terbuka membentuk belukar yang menutupi tanah-tanah kosong. Pteridophyta di lahan terbuka kebanyakan hidup soliter dan tumbuh lebih lambat dari Pteridophyta di daerah ternaungi (LIPI 1980).

Pteridophyta memiliki banyak manfaat bagi manusia, yaitu sebagai tanaman hias sebagai contoh Platycerium, Adiantum, Asplenium dan Sellaginela; sebagai sayuran yaitu Marsilia crenata, Pteridium aquilinu: sebagai dekorasi dan karangan bunga yaitu Gleichenia linearis, sebagai bahan pembersih yaitu Equisetum, sebagai bahan obat-obatan yaitu Aspidium filixmas, Lycopodium clavatum (Mirna, 2010). Fungsi ekologi Pteridophyta sebagai salah satu komponen pembentuk vegetasi hutan mampu menahan limpasan air hujan yang bermanfaat untuk mengurangi debit banjir dan penahan air yang berfungsi sebagai sumber air (Polunin, 2004).

$$
\text { Tumbuhan Pteridophyta }
$$

diajarkan di sekolah pada bidang studi biologi mulai tingkat sekolah dasar sampai 
perguruan tinggi pada jurusan tertentu terutama jurusan biologi. Di Sekolah Menengah pengajaran Pteridophyta menurut Pedoman KBK Mata Pelajaran Biologi yang diterbitkan Departemen Pendidikan Nasional Badan Penelitian dan Pengembangan Pusat Kurikulum Jakarta, tercantum dalam Kompetensi Dasar : Melakukan kegiatan kerja ilmiah (mengamati, mengelompokkan, mengkomunikasikan, menafsirkan, mengajukan pertanyaan) dengan materi pengelompokan atau penggolongan dengan indikator: Menemukan perbedaan dan persamaan ciri berbagai objek biologi berdasarkan morfologi dan anatomi; Melakukan klasifikasi berdasarkan ciri yang teramati dan Menggunakan kunci determinasi sederhana pada beberapa spesies yang diberikan (2001).

Piket Nol Pronojiwo Lumajang memiliki karakteristik klimatologi curah hujan cukup tinggi yaitu $2200 \mathrm{~mm} /$ tahun, tinggi tempat antara 548.64 sampai dengan $731.52 \mathrm{Mdpl}$, suhu rata-rata $20^{\circ} \mathrm{C}-30^{\circ} \mathrm{C}$. Dengan letak astronomis antara $112^{\circ} 54^{\prime} 09^{\prime \prime}$ - $113^{\circ} 01^{\prime} 09^{\prime \prime}$ BT dan 8 $06^{\prime} 30^{\prime \prime}$ $-8^{\circ} 15^{\prime} 43^{\prime \prime}$ LS (Agus, 2011). Kawasan ini mudah dijangkau karena dilalui Jalan Raya Malang - Lumajang. Berdasarkan hasil KKL matakuliah Botani Tumbuhan Tinggi Jurusan pendidikan Biologi Universitas Muhammadiyah Malang ditemukan 3 kelas anggota Pteridophyta dari 4 kelas yang ada. Namun sampai saat ini belum didapatkan data publikasi tentang jenisjenis dan belum dilakukan penelitian untuk penggunaan sebagai sumber belajar di sekolah.

\section{METODE}

Jenis penelitian yang digunakan dalam penelitian ini adalah jenis penelitian deskriptif. Penelitian ini dilakukan untuk mengidentifikasi jenis-jenis Pteridophyta yang ada di hutan Pronojiwo Kabupaten Lumajang serta pemanfaatanya sebagai sumber belajar biologi dengan metode FGD (Focus Group Discusion) dengan peserta guru SMA Mataram Tempursari Lumajang.

Sampel yang digunakan dalam penelitian ini adalah jenis Pteridophyta yang ditemukan dalam penelitian di kanan kiri jalan raya Malang-Lumajang pada Pasirian Km. 16 sampai dengan $\mathrm{Km}$. $18+700$ di piket nol pronojiwo Kabupaten Lumajang. Teknik pengambilan sampel dengan sistem transek dengan membuat petak contoh 20 × 20 meter. Sepanjang kanan kiri jalan raya Malang Lumajang mulai Pasirian Km 14 sampai dengan Km 18, jarak antar transek 200 meter. Penentuan luas petak contoh 20 x 20 meter dengan pertimbangan banyak Pteridophyta yang epifit pada pohon, sehingga menggunakan luas petak contoh pada pohon. Dimana menurut Siti Latifah, 2005 luas petak pohon adalah $20 \times 20$ meter, sebelum dilakukan pengambilan pteridophyta difoto terlebih dahulu sehingga didapatkan hasilberupa foto serta tumbuhan pteridophyta yang nantinya diherbarium.

Pteridophyta yang ditemukan dimanfaatkan untuk sumber belajar dengan menentukan standart kompetensi dan kompetensi dasar yang sesuai untuk pengajaran biologi di tingkat SMA. Kemudian Pemanfaatan sebagai sumber belajar dilakukan dengan menyusun Rencana Pelaksanaan Pembelajaran (RPP) dan LKS,Untuk kelayakan RPP yang disusun serta kelayakan pemanfaatan Pteridopyta Piket Nol Pronojiwo Lumajang sebagai sumber belajar dilakukan FGD dengan guru-guru IPA SMA MATARAM Tempursari Lumajang,Berdasarkan masukan dari kegiatan FGD dilakukan revisi pada RPP yang telah disusun.

\section{HASIL}

Berdasarkan hasil penelitian jenis Pteridophyta di Piket Nol Pronojiwo Lumajang di dapatkan data seperti pada tabel 1 . 
Tabel 1. Hasil Penelitian Jenis Pteridophyta di Piket Nol Pronojiwo Lumajang.

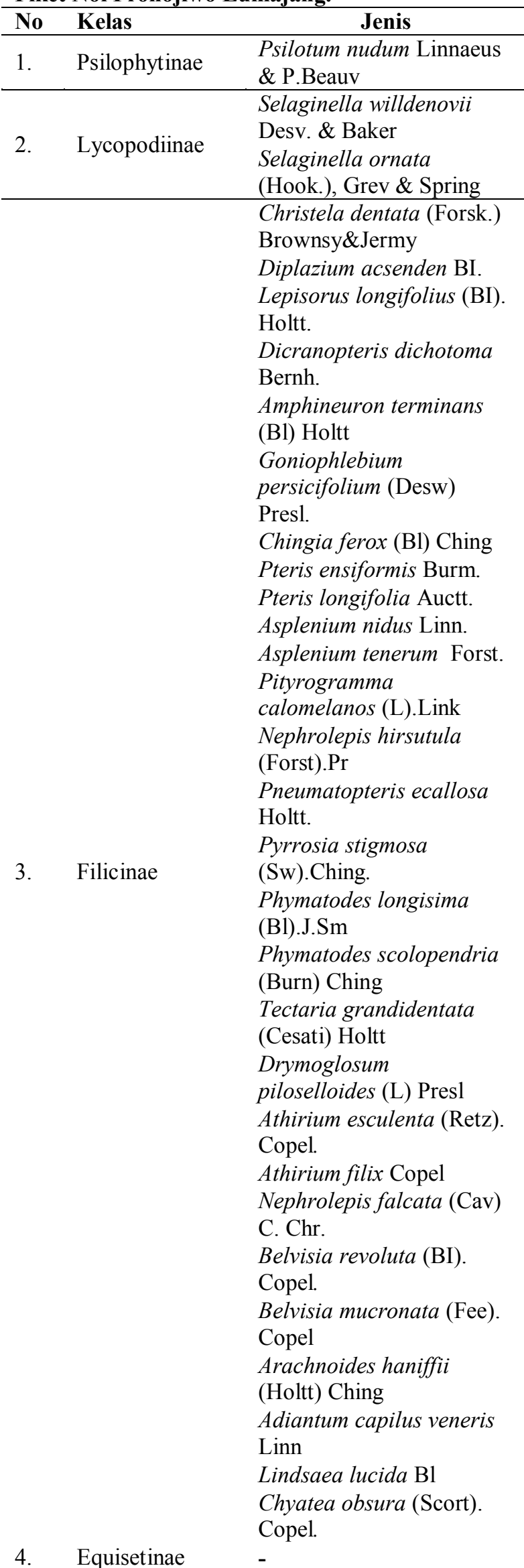

\section{Hasil Identifikasi Pteridhophyta di Piket Nol Pronojiwo Lumajang}

\section{Silotum nudum Linnaeus \& P.Beauv}

Herba kecil rendah, dan bercabang-cabang menggarpu, tumbuhan ini sama sekali tidak berakar hanya mempunyai tunas-tunas tanah dengan rizoid-rizoid, pada batang terdapat mikrofil (daun-daun kecil) berbentuk sisik, tidak bertulang dan tersusun jarang-jarang dalam garis spiral. Sporokarp tidak terminal pada ujung batang atau cabang-cabang, tetapi di antara taju-taju sporofil yang berbagi menggarpu (Tjitrosoepomo, 1994: 216).

\section{Selaginella willdenovii Desv. \& Baker}

Batang tegak dan bersisik halus, percabangan menyirip. Ental berwarna hijau, bulat lonjong. Licin dan agak kaku, ental subur dalam bentuk stobili berbentuk tabung (Tjitrosoepomo, 1994: 225).

\section{Selaginella ornata (Hook.)}

Batang menjalar, ental kecil, tipis berseling pada batang, bercabang dua, kemudian cabangnya bercabang dua lagi begitu seterusnya, ental-ental subur tersusun di dalam karangan menyerupai bulir yang disebut strobili. Strobili terletak di ujung percabangan berwarna hijau keputihan (Tjitrosoepomo, 1994: 224).

\section{Christela dentata (Forsk.)} Brownsy\&Jermy

Sorus berada di bagian bawah daun, tersusun rapi kanan dan kiri. Sorus terletak di tengah urat daun. Sorus yang berkumpul membentuk sori yang dilindungi oleh rambut- rambut halus (Common Ferns of The Philippines, 1994. Hal 28), (Piggott, 1998: 219).

\section{Diplazium acsenden BI.}

Terestrial, batang berwarna hijau, rhizome kadang berasal dari tangkai ental, panjang ental $0,4-1,5 \mathrm{~m}$, dengan lebar 30 - 
$50 \mathrm{~cm}$, bagian permukaan atas ental berwarna hijau gelap, licin, bagian bawah permukaan hijau keputihan, memiliki papila kecil dan pada ental memiliki cuping. Terkadang tumbuh calon individu baru pada ketiak anak daun. Sori tersusun di antara anak tulang daun memanjang sampai pinggiran ental. Berwarna putih kehijauan saat muda dan berwarna coklat saat matang (Holtum, 1968: 558).

\section{Lepisorus longifolius (BI). Holtt.}

Bentuk Sorus lonjong, tenggelam pada helaian daun, daun panjang dan urat daun tidak tampak, sedangkan tulang daun utama tampak (Holttum, 1968: 266).

\section{Dicranopteris dichotoma Bernh.}

Rhizome panjang, menjalar, pucuk berwarna hijau pucat, ditutupi bulu-bulu hitam, batang licin berwarna coklat kehitaman, tangkai ental berwarna hijau kekuningan, ental berwarna hijau, tiaptiapcabang bercabang dua, masing-masing cabang bercabang lagi. Sori terdapat disetiap anak daun dan penyebaranya terbatas disepanjang tulang daun, berwarna hijau keputihan saat mudan dan berwarna coklat saat tua (Holtum, 1968:69).

\section{Amphineuron terminans (Bl) Holtt}

Sorus berbentuk bulat, berada di bagian ujung anak daun (pinna). Indisium menutupi setiap Sorus, indisium pada tumbuhan ini adalah indisium asli yaitu penutup yang merupakan perkembangan dari epidermis bawah daun (Holtum, 1968).

\section{Goniophlebium persicifolium (Desw) Presl.}

Epifit, rimpang menjalar berwarna hitam, tangkai ental berwarna hitam licin, ental majemuk dengan pinggiran bergelombang, berwarna hijau, licin, panjang, ental $80-100 \mathrm{~cm}$, sori terdapat diantara anak-anak tulang daun, sejajar berwarna hijau kekuningan saat masih muda dan berwarna coklat saat matang (Holtum, 1968: 296).
Berdasarkan ciri-ciri di atas maka dapat di ketahui klasifikasinya Epifit, rimpang menjalar berwarna hitam, tangkai ental berwarna hitam licin, ental majemuk dengan pinggiran bergelombang, berwarna hijau, licin, panjang, ental $80-100 \mathrm{~cm}$, sori terdapat diantara anak-anak tulang daun, sejajar berwarna hijau kekuningan saat masih muda dan berwarna coklat saat matang (Holtum, 1968: 296).

\section{Chingia ferox (B1) Ching.}

Sorus terletak di tengah tulang daun, posisi daun berseling, batang terdapat bulu rambut (Holttum, 1968).

\section{Pteris ensiformis Burm.}

Paku tanah, 0,15-0,70 m. Akar rimpang tegak atau merayap, pendek dan beruas pendek. Daun gundul, tegak, menyirip rangkap, kuat, tidak beruas dengan akar rimpang. Panjang daun steril 5-20 cm, di atas tangkai dari 5-20 cm, sirip akhir 5-8 cm, sirip samping kedua belah sisi 3-7, bertangkai pendek atau duduk; anak daun kedua belah sisi dari poros, sirip 1-4, memanjang bulat telur terbalik, membulat atau tumpul, bergerigi tajam, 12 kali 4-6 mm, yang terbawa kerap kali berbagi, anak daun terujung adalah terpanjang. Daun fertile jelas berbeda dengan yang steril, panjang $20-40 \mathrm{~cm}$, di atas tangkai yang panjangnya $10-20 \mathrm{~cm}$, anak daun atau taju daun berbentuk garis, lebar 2-4 mm, tepi rata, tetapi yang pada ujung bergerigi. Sori pada sisi bawah daun di atas urat daun yang berjalan sepanjang tepi, tertutup oleh tepi daun yang tipis seperti selaput dan menggulung. Ada bentuk antara anak daun fertile dan steril. Seluruh Jawa, 5-900 m. (Stenis, 2002: 95).

\section{Pteris longifolia Auctt.}

Paku tanah, 0,15-0,70 m. Akar rimpang tegak atau merayap, pendek dan beruas pendek. Daun gundul, tegak, menyirip rangkap, kuat, tidak beruas dengan akar rimpang. Panjang daun steril 5-20 cm, di atas tangkai dari 5-20 cm, sirip 
akhir 5-8 cm, sirip samping kedua belah sisi 3-7, bertangkai pendek atau duduk; anak daun kedua belah sisi dari poros, sirip 1-4, memanjang bulat telur terbalik, membulat atau tumpul, bergerigi tajam, 12 kali 4-6 mm, yang terbawa kerap kali berbagi, anak daun terujung adalah terpanjang. Daun fertile jelas berbeda dengan yang steril, panjang $20-40 \mathrm{~cm}$, di atas tangkai yang panjangnya $10-20 \mathrm{~cm}$, anak daun atau taju daun berbentuk garis, lebar 2-4 $\mathrm{mm}$, tepi rata, tetapi yang pada ujung bergerigi. Sori pada sisi bawah daun di atas urat daun yang berjalan sepanjang tepi, tertutup oleh tepi daun yang tipis seperti selaput dan menggulung. Tidak Ada bentuk antara anak daun fertile dan steril (Stenis, 2002: 95).

\section{Asplenium nidus Linn.}

Ental tunggal, panjang ental 15-1,2 m, lebar 5-15 cm, tepinya rata dengan permukaan berombak, warnaental bagian bawah hijau pucat, tangkai ental sangat pendek, hampir tidak kelihatan, berwarna coklat. Sori terletak dipertulangan ental bagian bawah. Berwarna coklat tua, tersusun menyirip (Holtum, 1968: 305).

\section{Asplenium tenerum Forst}

Sorus terdapat di bagian bawah daun, letaknya sejajar dengan anak tulang daun. Tangkai daunnya pendek atau daun duduk. Sirip semakin ke atas semakin mengecil dan akhirnya membentuk satu daun. Sori pada sisi bawah daun di bawah tepi taju daun yang menggulung, tepi daun tersebut juga berfungsi menjadi selaput penutup, melintang memanjang sampai pendek berbentuk garis, lurus atau bengkok (Stenis, 2002: 95).

\section{Pityrogramma calomelanos (L).Link}

Habitat terestrial, sisi bawah daun tertutup bedak putih (lapisan lilin). Sori mengikuti urat, daun menyirip rangkap 2 atau lebih (Steenis, 2002: 91).

\section{Nephrolepis hirsutula (Forst).Pr}

Daun menyirip, pangkal daun tertaancap pada batang, tunas adventiv pada akar. Sorus berbentuk jantung, terdapat pada tepi permukaan bawah daun (Holtum, 1968).

\section{Pneumatopteris ecallosa Holtt.}

Teresterial, batang berwarna hijau kecoklatan, terdapat garis putih jaringan udara. Ental berwarna hijau dibagian permukaan, dan berwarna hijau pucat di bagian permukaan bawah, kasap, panjang ental antara 100-120 cm, dengan lebar 30$60 \mathrm{~cm}$, memiliki aurikel dibagian paling bawah, sebelum anak daun, mengellingi batang. Sori tersusun dibagian kanan dan kiri anak tulang daun dan berada di bagian tengahnya, berwarna putih kehijauan saat masih muda dan berwarna coklat gelap saat matang (Holttum, 1968).

\section{Pyrrosia stigmosa $(\mathrm{Sw})$.Ching}

Epifit, rhizome menjalar, bersisik, berwarna coklat, ujung rhizome berwarna agak keemasan, tangkai empal sangat pendek, seluruh permukaan ental ditutupi bulu-bulu halus berwarna coklat kemerahan, panjang ental 25-45 cm, dengan lebar 3-6 cm, apex ental tumpul. Ada dua jenis ental,pada permukaan bawah ental steril ditutupi bulu-bulu halus yang rapat seperti sisik, berwarna coklat kemerahan, sedangkan ental fertil diturupi oleh sori yang tersusun antara urat-urat daun. Sori berwarna kuning saat muda, dan berwarna coklat saat matang, sori hanya terdapat pada duapertiga bagian apex ental (Holtum, 1968: 147).

\section{Phymatodes longisima (Bl).J.Sm}

Epifit dan teresterial, ental memiliki panjang 50-100 cm, dengan lebar 20-25 $\mathrm{cm}$, berwarna hijau mengkilat bertoreh dalam. Sori terdapat di kanan dan kiri pertulangan ental, berada pada cekungan yang dalam, sekitar 1-1,5 mm, Sorus muda berwarna kuning kehijauan dan berwarna coklat saat matang (Holttum, 1968: Lubis, 2009: 106). 


\section{Phymatodes scolopendria (Burn)}

Ching

Rizome panjang, antara $7 \mathrm{~mm}$ Epifit dan teresterial, ental memiliki panjang 50$100 \mathrm{~cm}$, dengan lebar $20-25 \mathrm{~cm}$, berwarna hijau mengkilat bertoreh dalam. Sori terdapat di kanan dan kiri pertulangan ental, berada pada cekungan yang dalam, sekitar 1-1,5 mm, Sorus muda berwarna kuning kehijauan dan berwarna coklat saat matang (Holttum, 1968: Lubis, 2009: 106)

\section{Tectaria grandidentata (Cesati) Holtt}

Rimpang pendek, ental tunggal dengan torehan yang dalam, setiap tulang daun dihubungkan oleh torehan ental pada ental muda torehan belum terlihat, permukaan ental di bagian atas dan agak kasap di bawah, panjang ental $85-125 \mathrm{~cm}$, dengan lebar 30-50 cm, tersebar di bawah permukaan ental, diantara urat-urat ental, berwarna coklat (Holtum, 1968: 503: Piggot, 1964: 348).

\section{Drymoglosum piloselloides (L) Presl}

Epifit, akar rimpang panjang, kecil, merayap, besisik, sisik menempel kuat. Daun tepi rata, dimorfus, kaki lancip, ujung membulat atau tumpul, berdaging. Daun fertil bertangkai pendek atau duduk oval memanjang, yang fertil jauh lebih panjang berbentuk garis. Sori panjang sejajar dan dengan jarak tertentu dengan tulang daun tengah, pada ujung selalu mendekat (Stenis, 2002: 92).

\section{Athyrium esculenta (Retz). Copel}

Memiliki tekstur daun agak kaku, tepi daun bergerigi, ujung daun meruncing, pangakal daun berlekuk, permukaaan daun halus, pertulangan daun menyirip yang ujungnya sampai pada tepi anak daun dan berwarna hijau gelap. Etal muda ditutupi sisik coklat muda (Holttum, 1968: 543).

\section{Athyrium filix Copel.}

Sorus terletak di tepi daun berbentuk tapal kuda. Sorus melengkung seperti bulan sabit tertutupi reniform coklat keputihan, berbentuk ginjal dan memiliki indisium (Holtum, 1968: 266)

25. Nephrolepis falcata (Cav) C. Chr.

Paku tanah jarang epifit, akar rimpang, tegak berdaun lebat, tangkai daun $10-60 \mathrm{~cm}$, pangkalnya gundul atau bersisik jarang. Helaian daun dari tanaman yang normal 20-120 kali 5-16 cm., kerapkali kaku tegak, poros gundul. Anak daun duduk atau hampir duduk, kerap kali dengan sisik yang berkapur, yang terbawah agak berjauhan, kecil yang lebih tinggi terkumpul rapat,ujung menyempit lancip. Pinnae subur sempit daripada yang steril dan sori memiliki indusia kecil berkembang hanya di margin (Piggot, $1988: 375$ ).

\section{Belvisia revoluta (BI). Copel.}

Rhizome bersisik runcing, berwarna coklat gelap. Memiliki dua jenis ental, steril memiliki panjang 10-12 cm, berbentuk lanset, ental fertil dengan panjang $15-20 \mathrm{~cm}$, lebar $3-5 \mathrm{~cm}$, sori tersusun dipinggir ental dibagian bawah berwarna coklat (Holttum, 1968).

\section{Belvisia mucronata (Fee). Copel}

Hidup epifit (menempel) di batang pepohonan, sorus tersebar di atas permukaan yang lebih rendah seperti di ujung dan berwarna kecoklatan. Akar pendek merambat (Holttum, 1968).

\section{Arachnoides haniffii (Holtt) Ching}

Teresterial, helaian ental licin, berwarna hijau gelap, terkadang terlihat kebiruan, permukaan bagian bawah berwarna hijau pucat, anak daun saling berdekatan di bagian ujung dari anak daun terlihat seperti gigi. Sori terdapat di bagian ujung anak tulang daun, berwarna coklat kehitaman. Rimpang panjang, menjalar, berbulu kaku, berwarna coklat, panjang ental keseluruhan 35-65 cm, dengan lebar 15-22 cm (Holttum, 1968 ). 


\section{Adiantum capilus veneris Linn}

Tangkai daun hitam mengkilat dan halus, batangnya sangat pendek berada di antara tangkai daun. Sorus berbentuk ginjal di bagian tepi daun dan daunnya kelihatan rapat antara daun yang satu dengan yang lain (Holtum, 1968: 599).

\section{Lindsaea lucida B1}

Helaian anak daunnya memiliki bentuk seperti kipas. Tekstur meskipun kaku tetapi tipis. Warnanya hijau gelap, mengkilap. Sorinya tumbuh di tepi anakanak daun yang subur, tetapi hanya di bagian atas saja (Kerabat Paku: hal. 65).

\section{Chyatea obsura (Scort). Copel.}

Sorus banyak mengandung sporangium, tidak pada tepi daun melainkan pada permukaan bawah, bentuk bola, indisium tidak ada atau jika ada berbentuk bola, piala atau mangkuk, seringkali amat kecil. Daun tersusun sebagai rozet batang, menyirip ganda yang masih muda tegak atau serong, akhirnya daun yang telah kering bergantung. Sorus agak jauh dari tepi daun yang muda diliputi oleh indisium bentuk bola (Holtum, 1968: 127).

B. Penggunaan Pteridophyta Piket Nol Pronojiwo Lumajang Sebagai Sumber Belajar Di Sekolah.

Pada penelitian ini ditemukan 31 Jenis yang tergolong pada 3 kelas dari 4 kelas yang ada. Penggunaan hasil penelitian ini sebagai sumber belajar bilogi di sekolah di dasarkan pada hasil rancangan RPP dan LKS yang telah disusun dan di diskusikan dengan guru SMA Mataram Tempur Sari Lumajang. Pemilihan SMA Mataram di dasarkan pada kedekatan lokasi SMA dengan lokasi penelitian. Pada awal perencanaan peneliti menyusun 3 alternatif cara pemakaian sebagai sumber belajar yaitu menggunakan metode karya wisata, penggunaan foto dan herbarium. Hal terpenting yang didapat dari FGD dengan guru di SMA Mataram Tempursari Lumajang adalah: cara penggunaan sebagai sumber belajar yang paling sesuai adalah herbarium, sebab penggunaan hernarium dipandang lebih praktis, murah dan dapat digunakan secara klasikal. Metode karya wisata terbentur dengan waktu mengingat pengajaran Pteridophyta di sekolah, merupakan bagian dari KD 3.3 Mendeskripsikan ciri-ciri Divisio dalam Dunia Tumbuhan dan peranannya bagi kelangsungan Hidup di Bumi. Pada KD tersebut selain Pteridophyta masih dibahas 5 divisi lainnya yaitu Monera, Protista, Fungi, Alga, Bryophyta, dan Spermatophyta. Dengan demikian penggunaan karyawisata tidak sesuai dengan alokasi waktu program semester.

Usulan peneliti untuk menggunakan metode karya wisata terpadu untuk semua KD 3 dan penggunaan foto, tidak disetujui forum dengan pertimbangan bahasan Monera, Protista dan Fungi tidak mudah ditemukan di Piket Nol Pronojiwo Lumajang. Cara penggunaan sumber belajar dengan foto dianggap kurang sesuai untuk sekolah, sebab penggunaan foto dengan ukuran kertas A4 akan mahal, alternatif penggunaan foto dengan LCD dinilai forum tidak semua sekolah menyediakan LCD, selain itu dengan mengamati gambar LCD anak tidak bisa bebas membandingkan satu obyek dengan obyek lainnya.

Berdasarkan hasil FGD selain cara pemakaian seperti yang tersebut di atas, rancangan RPP dan LKS yang dipresentasikan peneliti mendapatkan revisi pada alokasi waktu dan pelaksanaan pembelajaran. Namun pada prinsipnya penggunaan hasil penelitian Pteridophyta di Piket Nol Pronojiwo Lumajang untuk sumber belajar dengan menggunakan herbarium layak untuk digunakan. KD $\begin{array}{llll}\text { yang sesuai adalah KD } & 3.3\end{array}$ Mendeskripsikan ciri-ciri Divisio dalam Dunia Tumbuhan dan peranannya bagi kelangsungan Hidup di Bumi, sedangkan indikator yang dikembangkan adalah mendeskripsikan ciri-ciri morfologi tumbuhan paku dan mengklasifikasikan 
tumbuhan paku. Hasil FGD meliputi usulan peserta, RPP dan LKS hasil penyempurnaan untuk penggunaan hasil penelitian Pteridophyta di Piket Nol Pronojiwo Lumajang terlampir.

\section{PEMBAHASAN}

Berdasarkan penelitian ditemukan 31 jenis Pteridophyta di Piket Nol Pronojiwo Lumajang yang termasuk dalam 3 kelas dari 4 kelas yang ada. Jenis-jenis tersebut adalah dari Kelas Psilophytinae adalah Psilotum nudum Linnaeus \& P.Beauv. Dari Kelas Lycopodiinae adalah Selaginella willdenovii Desv. \& Baker, Selaginella ornata (Hook.), Grev \& Spring, Dari Kelas Filicinae adalah, Christela dentata (Forsk.) Brownsy\&Jermy, Diplazium acsenden BI., Lepisorus longifolius (BI). Holtt., Dicranopteris dichotoma Bernh., Amphineuron terminans (Bl) Holtt, Goniophlebium persicifolium (Desw) Presl., Chingia ferox (Bl) Ching., Pteris ensiformis Burm., Pteris longifolia Auctt., Asplenium nidus Linn., Asplenium tenerum Forst., Pityrogramma calomelanos (L).Link, Nephrolepis hirsutula (Forst).Pr, Pneumatopteris ecallosa Holtt., Pyrrosia stigmosa (Sw).Ching., Phymatodes longisima (B1).J.Sm, Phymatodes scolopendria (Burn) Ching, Tectaria grandidentata (Cesati) Holtt, Drymoglosum piloselloides (L) Pres1, Athirium esculenta (Retz). Copel., Athirium filix Copel.

Nephrolepis falcata (Cav) C. Chr., Belvisia revoluta (BI). Copel., Belvisia mucronata (Fee). Copel, Arachnoides haniffii (Holtt) Ching, Adiantum capilus veneris Linn, Lindsaea lucida Bl, Chyatea obsura (Scort). Copel.

Pada Penelitian di Piket Nol Pronojiwo Lumajang ditemukan banyak variasi paku yaitu 3 kelas yang memiliki 31 jenis, hal ini karena Piket Nol Pronojiwo Lumajang merupakan kawasan dengan vegetasi penutup utama berbentuk hutan tropika basah. Dimana ditunjukkan oleh keberadaan 7 jenis vegetasi hutan penyusun vegetasi hutan tropika basah yaitu pohon-pohon hutan yang membentuk tajuk atau canopy, terna pada lantai hutan, tumbuhan pemanjat atau liana, epifit, tumbuhan pencekik dari marga Ficus, tumbuhan saprofit dan tumbuhan parasit. Menurut Polunin, 1994: daerah dengan tutupan vegetasi seperti itu termasuk hutan tropika basah. Curah hujan Piket Nol Pronojiwo Lumajang cukup tinggi yaitu, $2200 \mathrm{~mm} /$ tahun, tinggi tempat antara 548.64 sampai dengan $731.52 \mathrm{MDpl}$, suhu rata-rata $20^{\circ} \mathrm{C}-30^{\circ} \mathrm{C}$. Dengan letak astronomis antara 112 $54^{\prime} 09^{\prime \prime}$ $113^{\circ} 01^{\prime} 09^{\prime \prime}$ BT dan 8 $06^{\prime} 30^{\prime \prime}-8^{\circ} 15^{\prime} 43^{\prime \prime}$ LS (Agus, 2011). Kondisi hutan tropika basah dengan karakteristik klimatologi tersebut di atas yang menyebabkan Piket Nol Pronojiwo Lumajang memiliki keanekaragaman Pteridophyta yang beragam.

Dengan kondisi vegetasi dan klomatologi di atas akan mendukung tumbuhnya berbagai jenis Pteridophyta. Pteridophyta yang ditemukan adalah kelompok yang epifit maupun terestrial namun ternaungi yang merupakan habitat yang sesuai untuk Pteridophyta (LIPI, 1980). Ketinggian tempat juga sangat mendukung muncul berbagai jenis Pteridophyta, Piket Nol Pronojiwo Lumajang termasuk kawasan dataran rendah. Menurut Anwar, semakin tinggi tempat kelimpahan pepohonan dan epidit makin berkurang (1987).

Penyebaran jenis Pteridophyta di Piket Nol Pronojiwo Lumajang sangat bervariasi, penyebaran tertinggi di miliki oleh Asplenium nidus, hal ini terjadi karena Asplenium epifit pada pohon (Tjitrosoepomo, 1984: Stenis, 2002). Kondisi kawasan yang masih didominasi pohon akan sesuai sebagai habitat Asplenium nidus. Variasi penyebaran yang terjadi pada jenis-jenis Pteridophyta dikarenakan Piket Nol Pronojiwo Lumajang memiliki variasi pencahayaan, daerah di sisi kanan lebih banyak tertutup vegetasi pohon, sedangkan sebelah kiri lebih terbuka. Menurut Latifah dalam 
penelitiannya di Samosir Sumatra Utara, suhu udara, tanah dan intensitas cahaya berpengaruh nyata terhadap keanekaragaman Pteridophyta (2002). Psilotum nudum memiliki frekuensi terkecil, hanya ditemukan pada satu plot dan dalam jumlah individu kecil. Hal ini disebabkan Psilotum nudum merupakan paku purba yang ditemukan tinggal pada beberapa tempat di Jawa (Tjitrosoepomo, 1994).

Berdasarkan hasil FGD di SMA Mataram Tempursari Lumajang, Pteridophyta Piket Nol Pronojiwo Lumajang layak digunakan sebagai sember belajar. Namun demikian penggunaan dengan metode karyawisata tidak sesuai dilakukan karena alasan waktu, penggunaan gambar juga sulit diterapkan karena keterbatasan dana di sekolah. Cara penggunaan yang efektif adalah penggunaan dengan herbarium.

Selain herbarium Pteridophyta yang ditemukan di Piket Nol Pronojiwo Lumajang, masih perlu penambahan obyek lain dalam penggunaan sebagai sumber belajar. Untuk mencapai indikator mendeskripsikan ciri-ciri morfologi tumbuhan paku masih perlu ditambah tumbuhan lumut dan Spermatophyta sebagai pembanding sehingga siswa mampu membedakan ciri Pteridophyta dengan kelompok tumbuhan lain yaitu lumut dan Spermatophyta. Sedangkan untuk indikator mengklasifikasikan tumbuhan paku, perlu penambahan kelas paku yang tidak ditemukan di Piket Nol Pronojiwo Lumajang yaitu Kelas Equisetinae.

\section{KESIMPULAN DAN SARAN}

\section{Kesimpulan}

Berdasarkanan penelitian Identifikasi Pteridophyta Di Piket Nol Pronojiwo Lumajang Sebagai Sumber Belajar Biologi, dapat disimpulkan:

1. Ditemukan 31 jenis Pteridophyta di Piket Nol Pronojiwo Lumajang yang termasuk dalam 3 kelas dari 4 kelas yang ada. Jenis-jenis tersebut adalah dari Kelas Psilophytinae adalah Psilotum nudum Linnaeus \& P.Beauv. Dari Kelas Lycopodiinae adalah Selaginella willdenovii Desv. \& Baker, Selaginella ornata (Hook.), Grev \& Spring, Dari Kelas Filicinae adalah, Christela dentata (Forsk.) Brownsy\&Jermy, Diplazium acsenden BI., Lepisorus longifolius (BI). Holtt., Dicranopteris dichotoma Bernh., Amphineuron terminans (Bl) Holtt, Goniophlebium persicifolium (Desw) Presl., Chingia ferox (Bl) Ching., Pteris ensiformis Burm., Pteris longifolia Auctt., Asplenium nidus Linn., Asplenium tenerum Forst., Pityrogramma calomelanos (L).Link, Nephrolepis hirsutula (Forst).Pr, Pneumatopteris ecallosa Holtt., Pyrrosia stigmosa (Sw).Ching., Phymatodes longisima (Bl).J.Sm, Phymatodes scolopendria (Burn) Ching, Tectaria grandidentata (Cesati) Holtt, Drymoglosum piloselloides (L) Presl, Athirium esculenta (Retz). Copel., Athirium filix Copel.Nephrolepis falcata (Cav) C. Chr., Belvisia revoluta (BI). Copel., Belvisia mucronata (Fee). Copel, Arachnoides haniffii (Holtt) Ching, Adiantum capilus veneris Linn, Lindsaea lucida Bl, Chyatea obsura (Scort). Copel

2. Pemanfaatan hasil penelitian Identifikasi Pteridophyta Di Piket Nol Pronojiwo Lumajang Sebagai Sumber Belajar Biologi dilakukan dengan cara pemakaian herbarium untuk pengajaran di sekolah, menggunakan metode diskusi dan kerja kelompok dengan menggunakan LKS.

\section{Saran}

Berdasarkan penelitian perlu dilakukan penelitian kelompok tumbuhan lain seperti halnya lumut dan 
Spermatophyta di Di Piket Nol Pronojiwo Lumajang Sebagai Sumber Belajar Biologi, mengingat di Piket Nol Pronojiwo Lumajang masih memiliki tutupan vegetasi yang bagus dan memiliki banyak kekayaan vegetasi selain Pteridophyta.

\section{DAFTAR RUJUKAN}

Abdullah, 2000. Ilmu Alamiah Dasar. Bumi aksara: Jakarta

Budi, 2007. Data kerusakan hutan. Departemen Kehutanan. Jakarta

Departemen Pendidikan Nasional. 2004. Kurikulum 2004: Standart Kompetensi Mata Pelajaran Sains. Departemen Pendidikan Nasional : Jakarta

Dewi, 2008. Mengenal Tumbuhan Paku Pteridophyta. Erlangga. Jakarta

Dimyati dan Mujiati, 2002. Belajar dan Pembelajaran. Rineka: Jakarta

Hasairin, 2003. Organ Pada Tumbuhan Tingkat Rendah. Bumi aksara. Jakarta

Holtum,1967. Ferns of Malaya. Mc Grawhill:Toronto

Loveles, 1995. Pteridophyta. Surya Pustaka. Jogjakarta

Lubis dan Siti, 2009. Keanekaragaman Dan Pola Distribusi Tumbuhan Paku Di hutan Wisata Alam Eden Kabupaten Toba Samosir Sumatra Utara. Thesis. Universitas Sumatra Utara, Padang
Muslikhah, 2002. Identifikasi Tumbuhan Paku (Pteridophyta) Di Hutan Trenggalek. Skripsi. UMM: Malang

Poerwanti, 1998. Jenis-Jenis Penelitian. Gramedia. Jakarta

Piggott, A.G., 1988, Ferns of Malaysia in Colour, Tropical Press SDN. BHD Kuala Lumpur, Malaysia.

Polunin. 2004. Gegrafi Tumbuhan, Aksara Pustaka: Bandung

Rano, D. 2010. Jenis Paku Indonesia. Artikel identifikasi tumbuhan. www. Center of plant.com

Richard, 1952. Ekologi Pteridophyta. Bumi insani. Surabaya

Sastrapradja, 2000. Jenis-Jenis Tumbuhan Paku . LBN LIPI : Bogor

Scarhman.2000. Media pembelajaran. Jurnal Penelitian. Bandung.

Simpson. 2006. Plant systematics. Elsevier Academic Press. New York

Smith. 1994. Potensi Tumbuhan Bagi Kehidupan. Surya pustaka. Bandung

Steenis, 2008. Flora untuk Sekolah di Indonesia. PT Pradya Paramita. Jakarta

Tjitrosoepomo, 1994. Taksonomi Tumbuhan (Taksonomi Khusus). Gadjahmada University Press. Jogjakarta

Wardah, 2000. Lycopodium Potensi Sebagai Tanaman Hias. Aksara Pustaka.Bandung. 